\title{
PALMITO DE CANA-DE-AÇÚCAR: NOVA OPÇÃO ALIMENTAR $\left({ }^{1}\right)$
}

\author{
ANISIO AZZINI $\left({ }^{2,5}\right)$, LEO ZIMBACK $\left({ }^{3,5}\right)$, CASSIA R.L. CARVALHO $\left({ }^{4}\right)$ \\ e ANTONIO ALBERTO COSTA $\left({ }^{2,5}\right)$
}

\begin{abstract}
RESUMO
No presente estudo, realizado no Centro Experimental de Campinas (IAC), em 1991, procedeu-se à extraçăo e à caracterização do palmito de cana como alimento humano, determinando-se algumas de suas propriedades químicas. O material genético utilizado foi o clone IAC 70-32, proveniente da Estaçăo Experimental de Piracicaba (SP), do Instituto Agronômico (IAC). O palmito de cana é um subproduto da cultura da cana, com teor de proteína $(2,10 \%)$ semelhante ao do palmito (Euterpe edulis) $(2,18 \%)$, podendo ser utilizado como alimento humano. Considerando seu peso médio $(8,29 \mathrm{~g})$ e o número de colmos de cana por hectare $(60.000)$, pode-se obter uma produção de palmito de cana da ordem de $483 \mathrm{~kg} / \mathrm{ha}$.
\end{abstract}

Termos de indexação: cana-de-açúcar, palmito de cana, propriedades químicas, alimento.

\section{ABSTRACT \\ SUGARCANE HEART: A NEW FOODSTUFF OPTION}

In this study, carried out in 1991, at the Experimental Center of the Instituto Agronômico, Campinas, State of Sāo Paulo, Brazil, the extraction produceres of sugar cane heart as a human food is described. The chemical properties of this new product were determined considering the sugar cane clone IAC 70-32. The sugar cane heart is a by-product of the sugar crop and can be used as a foodstuff with protein content (2.10\%) similar to the palm heart (2.18\%). Yieldings around $483 \mathrm{~kg} / \mathrm{ha}$ can be expected taken into account the number of sugar cane culms per hectare.

Index terms: sugar cane, sugar cane heart, chemical properties, food.

O cultivo da cana-de-açúcar tem sido o principal sustentáculo do programa energético nacional, produzindo, de maneira renovável, açúcar e álcool carburante. Vários subprodutos agrícolas e industriais são obtidos a partir desse cultivo, destacando-se o bagaço fibroso, a vinhaça e as pontas de cana. $O$ bagaço e a vinhaça são subprodutos já valorizados pela pesquisa científica e utilizados como matéria-prima em várias atividades econômicas, como as produções de fibras celulósicas para papel e fertilizantes (vinhaça).

\footnotetext{
() Enviađo para publicaçāo em 22 de outubro de 1991 e aceito em 14 de agosto de 1992.

(2) Seção de Plantas Fibrosas, Instituto Agronômico (IAC), Caixa Postal 28, 13001-970 Campinas (SP).

(3) Seção de Cana-de-Açúcar, IAC.

( ${ }^{4}$ Seção de Glícedes, Instituto de Tecnologia de Alimentos (ITAL), Caixa Postal 139, 13073-001 Campinas (SP).

$\left({ }^{5}\right)$ Com bolsa de pesquisa do CNPq.
} 
A ponta de cana, como subproduto do sistema produtivo da cana-de-açúcar, tem sido utilizada em algumas usinas como material forrageiro ou simplesmente deixada no campo para, posteriormente, ser queimada ou incorporada ao solo. Em testes preliminares, foi observado que tecnicamente é possível aproveitar a região meristemática (central) da ponta de cana, como palmito, à semelhança dos palmitos tradicionais, obtidos das palmeiras e bambu.

O objetivo do presente estudo foi extrair e caracterizar o palmito de cana como alimento humano, determinando algumas de suas propriedades químicas, comparando-as com as do palmito (Euterpe edulis) e com o broto de bambu (Dendrocalamus giganteus).

\section{Material e Métodos}

O material genético empregado para a extração de palmito de cana-de-açúcar foi o clone IAC 70-32, proveniente da Estação Experimental de Piracicaba (SP), do Instituto Agronômico (IAC). Foram coletados, ao acaso, cem colmos de cana, determinadas algumas características morfológicas do colmo de cana-de-açúcar e realizada a extração do palmito. Cada colmo foi dividido em duas partes: o colmo propriamente dito e a ponta de cana. Desta, após a eliminação das folhas e do cartucho, obteve-se o "ponteiro", constituído basicamente pelas bainhas das folhas e região apical do colmo. O palmito comestível foi obtido do "ponteiro" após a eliminação de suas partes fibrosas, representadas pelas bainhas das folhas e partes da região apical do colmo. $\mathrm{O}$ palmito é a região meristemática do colmo de cana, apresentando coloraçāo clara, textura macia e estrutura segmentada.

Além das características morfológicas do colmo e do "ponteiro", determinou-se o peso do palmito e seu rendimento em relação ao "ponteiro". A avaliação do palmito como alimento foi determinada por algumas de suas propriedades químicas, relacionadas com seus teores de proteína, matéria graxa, açúcares totais, fibras e ácido cianídrico, conforme método empregado por Ferreira et al. (1986).

\section{Resultados e Discussão}

O peso do palmito de cana e seu rendimento, bem como as características morfológicas do colmo e dos "ponteiro", encontram-se no quadro 1. Considerando o peso do palmito obtido $(8,29 \mathrm{~g})$ e o número médio dos colmos de cana por hectare (60.000), pode-se estimar uma produção de palmito de cana de 483 $\mathrm{kg} / \mathrm{ha}$. Deve-se ressaltar que essa produção é obtida de um subproduto da colheita da cana, as pontas. Para as características morfológicas determinadas, os valores médios obtidos foram de $1,38 \mathrm{~kg}$ (peso do colmo), 2,38 cm (diâmetro basal do colmo), $117,70 \mathrm{~g}$ (peso do "ponteiro") e 44,94 cm (comprimento do "ponteiro"). $O$ rendimento médio obtido em palmito foi de $7,04 \%$, calculado em relação ao "ponteiro", por ser este último a primeira etapa da obtenção de palmito, executada logo após o corte da cana, quando se separam os colmos das pontas.

Quadro 1. Peso do palmito e característcias morfológicas do colmo de cana-de-açúcar (clones IAC 70-32) $\left({ }^{1}\right)$

\section{Características}

Média

Desvio

padrão
Coeficiente

de variação
Peso do palmito da cana (g)

Rendimento do palmito (\%)

Peso do colmo (kg)

Diâmetro basal do colmo $(\mathrm{cm})$

Peso do "ponteiro" (g)

Comprimento do "ponteiro" (cm)

$\begin{array}{rrr}8,29 & 1,92 & 23,16 \\ 7,04 & 2,46 & 32,10 \\ 1,38 & 0,33 & 23,87 \\ 2,38 & 0,25 & 10,68 \\ 117,70 & 28,31 & 24,06 \\ 44,94 & 4,27 & 9,51\end{array}$

(1) Médias de cem colmos de cana. 
No quadro 2, aparecem os dados sobre a caracterização química do palmito de cana e sua comparação com os dados do palmito $(E$. edulis) e do broto de bambu (Dendrocalamus giganteus). Quanto aos teores de matéria graxa, açúcares totais e fibra, o palmito de cana é semelhante ao broto de bambu, produto típico da cozinha oriental, principalmente chinesa e japonesa. Além do aspecto químico, esses produtos sâo semelhantes, também, no aspecto físico, pois apresentam coloração clara, textura macia e estrutura segmentada. Os teores de proteína bruta observados no palmito de cana e no palmito tradicional foram, respectivamente, de 2,10 e 2,18\%. O palmito de cana (115 ppm), à semelhança do broto de bambu (435 ppm), pelos elevados teores de ácido cianídrico, devem ser cozidos, para eliminar esse componente tóxico, antes de serem consumidos como alimento.

Os dados obtidos, principalmente os relacionados com as propriedades químicas, evidenciam que $\mathbf{o}$ palmito de cana pode ser utilizado como alimento, com valor nutritivo semelhante ao do palmito e de broto de bambu.

Outros estudos, principalmente os relacionados com a extração e processamento, deverão ser efetuados para complementar e comprovar a viabilidade econômica dessa produção.

Quadro 2. Caracterização química do palmito de cana em comparação com o palmito tradicional e com o broto de bambu ( $\left.{ }^{1}\right)$

Análises

químicas
Palmito

de cana
Palmito

Broto de bambu
Proteína bruta $(\%)$

Matéria graxa (\%)

Açúcares totais (\%)

Fibra (\%)

Ácido cianídrico (ppm)

$$
\begin{aligned}
2,10 & \pm 0,035 \\
0,47 & \pm 0,059 \\
1,53 & \pm 0,19 \\
0,63 & \pm 0,072 \\
115,00 & \pm 2,800
\end{aligned}
$$

2,18

2,51

1,13

0,99

9,50
3,60

0,38

1,31

0,55

( $\left.{ }^{1}\right)$ Médias de três repetiçōes.

\section{CONCLUSŌES}

1. O palmito de cana é um produto com teor de proteína bruta semelhante ao palmito (E. edulis);

2. Para o material genético estudado (clone IAC 70-32), o peso médio do palmito comestível foi de $8,29 \mathrm{~g}$, sendo possível uma produção de palmito de aproximadamente $483 \mathrm{~kg} / \mathrm{ha}$;
3. A produção de palmito como subproduto do cultivo da cana-de-açúcar é tecnicamente possível e representa nova opção produtiva na agricultura.

\section{REFERÊNCIA BIBLIOGRÁFICA}

FERREIRA, V.L.F.; AZZINI, A.; FIGUEIREDO, I.B.; SALGADO, A.L.B. \& BARBIERI, M.K Avaliação do broto de espécies de bambu na alimentação humana. Coletânea do ITAL, Campinas, 16:23-36, 1986. 